\title{
Pengaruh Berbagai Macam Media terhadap Pertumbuhan Bibit Kelor (Moringa oleifera Lam.) Asal Stek Batang
}

\author{
The Effect of Various Media onThe Growth of Drum Stick \\ (Moringa oleifera Lam.) Seedling Derived From Stem Cutting \\ Sawaludin $^{1}$, Aluh Nikmatullah ${ }^{1}$, Bambang Budi Santoso ${ }^{2}$ \\ ${ }^{1)}$ Program Studi Agroekoteknologi Fakultas Pertanian UNRAM \\ ${ }^{2)}$ Kelompok Peneliti Bidang Ilmu Pertanian Lahan Kering, Fakultas Pertanian UNRAM \\ Fakultas Pertanian Universitas Mataram, \\ Jln Majapahit No. 62 Mataram NTB-INDONESIA Telp/Fax: 087701118243 \\ ${ }^{2)}$ Correspondence author: bambang.bs@unram.ac.id
}

Manuscript received: 10-03-2018. Accepted: 19-04-2018

\begin{abstract}
ABSTRAK
Penelitian ini bertujuan untuk mengetahui pengaruh berbagai macam media terhadap pertumbuhan stek batang kelor (Moringa oleifera Lam.). Penelitian dilaksanakan pada Maret-Mei 2017 di lahan pembibitan berlokasi di Dasan Agung, Mataram, pada ketinggian tempat $16 \mathrm{~m}$ dpl. Metode yang digunakan dalam penelitian ini adalah metode eksperimental dengan 6 macam media yaitu: tanah, tanah+serbuk gergaji, tanah+cocopeat, tanah+tongkol jagung, tanah+daun bambu, dan tanah+arang sekam. Rancangan percobaan diatur secara Acak Lengkap dengan 5 ulangan dan 5 unit serial. Hasil penelitian menunjukkan bahwa macam media berpengaruh nyata terhadap pertumbuhan bibit kelor asal stek batang. Media tanah+arang sekam dan tanah+cocopeat merupakan media yang baik digunakan untuk pembibitan tanaman kelor secara vegetatif menggunakan stek batang.
\end{abstract}

Kata kunci: arang sekam, cocopeat, daun bambu, serbuk gergaji, tongkol jagung

\begin{abstract}
This study aimed seedling derived from stem cutting to determine the effect of various media on the growth of drum stick (Moringa oleifera Lam.). Experiment was conducted from March to May 2017 in the nursery located in Dasan Agung, Mataram, with altitude of 16 meters above sea level. The method was experimental method with 6 media treatments: soil, soil+sawdust, soil+cocopeat, soil+corncob, soil+bamboo leaf, and soil+charcoal rice husk. The experimental design was Completely Randomized Design with 5 replications and 5 unit series. The result shows that the media significantly effect on the growth of sedling stem cutting. The best media forseedling derived from stem cutting were mixture media of soil+rice charcoal andsoil+cocopeat.
\end{abstract}

Keywords: bamboo leaf, charcoal husk, cocopeat, corn-cob, sawdust. 


\section{PENDAHULUAN}

Tanaman Kelor (Moringa oleifera Lam.) merupakan salah satu jenis tanaman yang mudah tumbuh di daerah tropis seperti Indonesia. Tanaman kelor dapat tumbuh subur pada dataran rendah sampai ketinggian $700 \mathrm{~m}$ di atas permukaan laut. Kelor dapat juga tumbuh pada daerah subtropis pada semua jenis tanah dan tahan terhadap musim kering dengan toleransi terhadap kekeringan sampai 6 bulan (Mendieta-Araica et al., 2013).

Sehubungan kandungan nilai gizi yang tinggi, khasiat, dan manfaatnya menyebabkan tanaman kelor mendapat julukan sebagai Mother's Best Friendl dan Miracle Tree. Daun kelor mengandung vitamin A, vitamin $\mathrm{C}$, vitamin $\mathrm{B}$, kalsium, zat besi, dan protein, dalam jumlah sangat tinggi yang mudah di cerna dan diasimilasi oleh tubuh manusia. Kelor mengandung lebih dari 40 antioksi dan mengandung 539 senyawa yang dikenal dalam pengobatan tradisional Afrika dan India (Ayurvedic) serta telah digunakan dalam pengobatan teradisional untuk mencegah lebih dari 300 penyakit (Krisnadi, 2015). Namun di Indonesia kelor masih belum banyak dimanfaatkan dan umumnya hanya digunakan sebagai sayuransegar (Santoso et al., 2017). Padahal, selain dikonsumsi langsung dalam bentuk segar, kelor juga dapat diolah menjadi bentuk tepung atau powder yang dapat digunakan sebagai bahan fortifikat untuk mencukupi nutrisi pada berbagai produk pangan, seperti pada olahan pudding, cake, nugget, biskuit, cracker, dan olahan lainnya (Aminah et al., 2015). Menurut Prajapati et al (2003) tepung daun kelor dapat ditambahkan pada setiap jenis makanan sebagai suplemen gizi.

Sebagai pangan fungsional, bagian daun, kulit batang, biji hingga akar dari tanaman kelor tidak hanya sebagai sumber nutrisi tetapi juga berfungsi sebagai herbal yang sangat berkhasiat untuk kesehatan (Simbolan et al., 2007). Saat ini penelitian dan uji klinis masih pada aspek tentang fungsi kelor sebagai obat meskipun manfaat dan khasiatnya belum banyak diketahui oleh masyarakat. Oleh karena itu maka pengembangan tanaman ini sangat perlu dilakukan.

Tanaman kelor dapat diperbanyak dengan setek batang maupun biji (Santoso dan Parwata, 2017; Krisnadi, 2015). Keunggulan teknik perbanyakan dengan biji adalah dapat menghasilkan tanaman dalam jumlah yang banyak (Santoso dan Parwata, 2017), sedangkan dengan menggunakan stek batang dapat diperoleh bibit dalam waktu yang singkat dan tanaman cepat menghasilkan buah (Krisnadi, 2015). Keunggulan lain perbanyakan dengan stek batang yaitu diperoleh tanaman yang memiliki sifat-sifat sama dengan pohon induknya. Selain itu tanaman hasil perbanyakan dengan stek batang lebih cepat berproduksi dibandingkan dengan tanaman yang ditanam dari biji (Hartman et al., 2002). Dalam usaha perbanyakan tanaman kelor, salah satu faktor yang mempengaruhi keberhasilan diperoleh bibit tanaman adalah media.

Penggunaan media tanam yang tepat akan menyediakan kondisi lingkungan yang optimal bagi pertumbuhan bibit asalstek. Media tanam yang baik memiliki kemampuan menyediakan nutrisi, air, dan udara yang optimum. Menurut Thompson dan Troeh (1978) tekstur, struktur, dan kandungan bahan organik di dalam suatu media menentukan baik tidaknya suatu media tanam. Hartman et al. (2002) menambahkan bahwa media tanam yang ideal harus memiliki syarat mempunyai aerasi dan drainase yang baik kelembaban cukup, bebas dari patogen dan bahan berbahaya, cukup hara dan berbobot ringan. 
Media tanam yang baik sangat ditentukan oleh jenis dan bahan media yang digunakan. Media tanam yang digunakan untuk pembibitan stek batang jarak pagar terdiri dari tanah lapisan atas (top soil) yang dicampur pupuk kandang dan pasir, serbuk serabut kelapa, sekam atau abu sekam.Bahan media tanam tidak digunakan secara tunggal, tetapi sebaliknya dikombinasikan antara bahan yang satu dengan yang lainnya (Ashari, 2006).

Keberhasilan pertumbuhan bibit tanaman hasil perbanyakan dengan stek batang ditentukan oleh pertumbuhan dan perkembangan akarnya. Akar tanaman hendaknya berada pada suatu lingkungan yang mampu memberikan pendukung struktural, memungkinkan absorbsi air dan nutrisi yang memadai. Pada sisi lainnya, media tanam menentukan drainase dan $\mathrm{pH}$ yang baik bagi tanaman. Media tanah tunggal juga cenderung memadat jika dilakukan penyiraman, dan tidak semua tanah memiliki kesuburan fisik, kimia, dan biologi yang baik untuk pertumbuhan bibit tanaman. Oleh karena itu, untuk mendapatkan media pembibitan yang baik dan subur, perlu dikombinasikan antara media tanah dengan bahan media pembibitan lainnya, khususnya media pembibitan berbahan dasar organik.

Khususnya pada perbanyakan atau pembibitan tanaman kelor dengan menggunakan stek batang, menggunakan media bahan organik belum tersedia informasi yang memadai. Artikel ini memaparkan hasil penelitian yang bertujuanuntuk mengtahuai jenis media pembibitan yang paling baik bagi pertumbuhan bibit asal stek batang tanaman kelor (Moringa oleifera Lam.).

\section{BAHAN DAN METODE}

Metode yang digunakan dalam penelitian ini adalah metode eksperimental yang dilaksanakan pada bulan Maret-Mei 2017 di lahan pembibitan yang berlokasi di Dasan Agung, Mataram, pada ketinggian 16 meter dpl. Keadaan mikroklimat di areal penelitian sebagai berikut: kelembaban $83 \%$, suhu $26.6-27.1{ }^{\circ} \mathrm{C}$, dan curah hujan berkisar antar 96-150 mm. Percobaan diatur menggunakan Completely Randomized Design dengan 6 macam media pembibitan sebagai perlakuan. Setiap perlakuan dibuat 5 ulangan dan pada masing-masing ulangan dibuat 5 unit serial, sehingga diperoleh 150 unit percobaan.

\section{Persiapan bahan stek batang}

Bahan stek batang diambil dari percabangan tanaman kelor yang berumur sekitar 15 tahun dan tumbuh subur di Dusun Panggung, Kabupaten Lombok Utara. Cabang yang lurus dan sehat berdiameter sekitar 3-5 cm diambil sepanjang $125 \mathrm{~cm}$, kemudian dibawa ke lokasi pembibitan. Pada lokasi pembibitan potongan stek batang tersebut dipotong menjadi dua dengan panjang $50 \mathrm{~cm}$. Potongan stek batang tersebut siap digunakan sebagai bahan percobaan.

\section{Pembuatan media}

Tanah. Media tanah yang digunakan berupa tanah sawah yang digali sedalam 20-25 $\mathrm{cm}$ (top soil). Tanah dibersihkan kemudian dikering-anginkan selama 1-2 hari. Setelah dikering-anginkan, tanah dapat dipakai dalam percobaan ini.

Serbuk gergaji. Bahan baku serbuk gergaji diperoleh dari limbah pemotongan kayu dengan berbagai jenis kayu kemudian di kering-anginkan. Serbuk gergaji yang telah siap digunak kemudian dicampurkan tanah dengan perbandingan 1:1 (v/v). 
Cocopeat. Bahan baku cocopeatdiambil dari limbah pembuatan sapu dari serabut kelapa. Kemudian direndam menggunakan air bersih selama 1 hari. Cocopeat dijemur selama 1-2 hari dan dicampurkan tanah dengan perbandingan 1:1 (v/v), kemudian diaduk hingga tercampur rata.

Hancuran tongkol jagung. Media hancuran tongkol jagung dipersiapkan dengan cara bahan baku tongkol jagung yang diperoleh dari limbah panenan jagung petani. Tongkol jagung kemudian dihancurkan hingga ukuran potongan-potongan berkisar antara 0,5-2,0 cm dan dijemur selama 1-2 hari. Hancuran tongkol jagung tersebut kemudian dicampurkan tanah dengan perbandingan 1:1 (v/v).

Seresah daun bambu. Media seresah daun bambu dipersiapkan dengan cara mengambil bahan seresah daun bambu di perkebunan bambu berupa daun yang sudah hancur atau terpotong dengan ukuran $0,5-1,0 \mathrm{~cm}$ pada lapisan terbawah dari tumpukan seresah daun bambu. Hancuran daun bambu dicampurkan tanah dengan perbandingan 1:1 (v/v), kemudian diaduk hingga tercampur merata.

Arang sekam. Arang sekam diperoleh dari nursery tanaman hias yang telah siap digunakan. Bahan tersebut kemudiandicampur tanah dengan perbadingan 1:1 (v/v), kemudian diaduk hingga tercampur merata.

Masing-masing dari keenam media pembibitan kemudian dimasukkan ke dalam polybag berukuran $25 \times 30 \mathrm{~cm}$ sesuai dengan jumlah unit percobaan yang telah ditentukan. Polybag yang telah berisi masing-masing jenis media diatur secara acak lengkap dan sudah siap ditanami stek batang kelor.

\section{Observasi dan Analisis data}

Variabel pertumbuhan bibit asal stek batang yang diamati meliputi, panjang tunas, jumlah tunas, jumlah daun, diameter tunas, bobot tunas segar, bobot kering tunas, jumlah akar, panjang akar, bobot akar segar, bobot kering akar, bobot batang stek awal, bobot batang stek akhir. Data terkumpul kemudian dianalisis menggunakan Anova 5\% dan diuji lanjut dengan menggunakan uji BNJ (beda nyata jujur) pada taraf 5\% apabila ada pengaruh dari perlakuan.

\section{HASIL DAN PEMBAHASAN}

Hasil penelitian menunjukkan bahwa macam media secara umum berpengaruh nyata terhadap pertumbuhan bibit asal stek batang kelor pada umur 56 hari setelah tanam (HST). Macam media berpengaruh tidak nyata terhadap beberapa parameter yang diamati pada saat bibit tanaman asal stek pada umur 14 HST-42 HST kecuali pada parameter diameter tunas saat bibit berumur 28 HST. Macam media berpengaruh nyata terhadap panjang tunas, jumlah akar, panjang akar, berat kering tunas, berat segar akar, dan berat kering akar bibit asal stek batang pada umur 56 HST. Sedangkan pada saat bibit berumur 70 HST macam media berpengaruh nyata terhadap jumlah daun dan pada umur 84 HST macam media berpengaruh nyata terhadap jumlah daun dan jumlah akar bibit.

Macam media berpengaruh tidak yata terhadap panjang tunas bibit asal stek batang kelor pada umur 14, 28, 42, 70, dan 84 HST, namun berpengaruh nyata terhadap panjang tunas pada saat bibit berumur 56 HST. Panjang tunas bibit pada berbagai umur disajikan pada Tabel 1. 
Macam media berpengaruh tidak nyata terhadap panjang bibit umur 14 HST dan menghasilkan panjang tunas stek kurang dari $1 \mathrm{~cm}$. Seiring dengan bertambahnya umur tanaman maka panjang tunas stek batang bertambah, meskipun berbeda tidak nyata sampai dengan umur 42 HST. Macam media berpengaruh nyata terhadap panjang tunas bibit asal stek pada umur 56 HST tunas bibit stek batang yang paling panjang terdapat pada media tanah+arang sekam yaitu $34.04 \mathrm{~cm}$ dan berbeda tidak nyata dengan bibit asal media tanah $(17.21 \mathrm{~cm})$, media tanah+cocopeat $(23.2 \mathrm{~cm})$, media tanah+tongkol jagung $(24.42 \mathrm{~cm})$, dan media tanah+seresah daun bambu $(13.86 \mathrm{~cm})$. Namun panjang tunas bibit asal stek batang terendah terdapat dan ditunjukkan oleh bibit pada perlakuan media tanah+serbuk gergaji yakni $7.72 \mathrm{~cm}$.

Tabel 1. Panjang tunas bibit stek kelor pada berbagai macam media tanam

\begin{tabular}{lcccccc}
\hline \multirow{2}{*}{ Macam media } & \multicolumn{7}{c}{ Panjang Tunas Bibit Stek $(\mathrm{cm})$} \\
\cline { 2 - 7 } & 14 & 28 & 42 & 56 & 70 & 84 \\
& HST & HST & HST & HST & HST & HST \\
\hline Tanah (T) & 0.48 & 2.01 & 7.24 & $17.21 \mathrm{ab}$ & 49.35 & 58.69 \\
T+serbuk gergaji & 0.41 & 0.80 & 3.15 & $7.72 \mathrm{~b}$ & 29.25 & 38.14 \\
T+cocopeat & 0.58 & 3.42 & 11.21 & $23.2 \mathrm{ab}$ & 50.86 & 57.81 \\
T+tongkol jagung & 0.23 & 1.95 & 12.13 & $24.42 \mathrm{ab}$ & 56.47 & 61.06 \\
T+seresah daun bambu & 0.30 & 1.41 & 5.83 & $13.86 \mathrm{ab}$ & 45.21 & 60.50 \\
T+arang sekam & 0.43 & 2.76 & 10.56 & $34.04 \mathrm{a}$ & 68.52 & 81.89 \\
\hline \multicolumn{1}{c}{ BNJ 5\% } & - & - & - & 23.08 & - & - \\
\hline
\end{tabular}

Keterangan: angka-angka yang diikuti huruf yangsama pada kolom yang samaberbeda tidak nyata pada uji BNJ 5\%, HST= Hari setelah tanam.

Media tanam yang kurang baik untuk pertumbuhan stek batang kelor terdapat pada media tanah+serbuk gergaji. Menurut Santoso et al. (2009), ada pengaruh negatif senyawa kimia hasil dekomposisi awal dari bahan serbuk gergaji kayu yang menyebabkan cekaman "alelopati" pada pertumbuhan dan perkembangan bibit. Kandungan air tinggi menyebabkan kurang aerasi dan mempercepat leaching senyawa penghambat tumbuh dari serbuk gergaji kayu.

Jumlah tunas dipengaruhi oleh karbohidrat yang terdapat pada sel tanaman. Indriyani et al. (1999) menyatakan bahwa akumulasi fotosintat yang tinggi menyebabkan pembesaran dan differensiasi sel yang dinyatakan dengan pertambahan tinggi, jumlah tunas, jumlah daun dan diameter batang.

Macam media berpengaruh tidak nyata terhadap jumlah tunas bibit asal stek hingga umur tiga bulan. Pada umur 14 HST jumlah tunas berkisar antara 1.35-2.2 dan 2.67-3.67 pada umur 84 HST (Tabel 2.). Macam media pembibitan tanaman asal stek batang kelor berpengaruh nyata terhadap diameter batang bibit pada saat umur 28 HST. Namun pada saat umur 42, 56, 70, dan 84 HST macam media pembibitan stek batang berpengaruh tidak nyata terhadap diameter tunas bibit. Diameter tunas bibit pada berbagai umur pengamatan tersebut disajikan pada Tabel 3. 
Tabel 2. Jumlah tunas bibit kelor pada berbagai macam media.

\begin{tabular}{lcccccc}
\hline \multirow{2}{*}{ Macam media } & \multicolumn{7}{c}{ Jumlah Tunas } \\
\cline { 2 - 7 } & HST & HST & HST & HST & HST & HST \\
\hline Tanah (T) & 1.65 & 1.75 & 1.80 & 2.44 & 2.83 & 3.06 \\
T+serbuk gergaji & 1.35 & 1.70 & 1.80 & 2.00 & 2.44 & 2.67 \\
T+cocopeat & 1.70 & 1.85 & 2.40 & 3.04 & 3.67 & 3.67 \\
T+tongkol jagung & 1.75 & 2.00 & 2.80 & 2.67 & 3.16 & 3.17 \\
T+seresah daun bambu & 1.90 & 2.05 & 2.00 & 3.08 & 3.17 & 3.17 \\
T+arang sekam & 2.20 & 2.42 & 2.40 & 2.88 & 3.28 & 3.28 \\
\hline BNJ 5\% & - & - & - & - & - & - \\
\hline
\end{tabular}

Keterangan: angka-angka yang diikuti huruf yang sama pada kolom yang sama berbeda tidak nyata pada uji lanjut BNJ 5\%, HST= Hari setelah tanaman

Tabel 3. Diameter tunas bibit pada berbagai macam media tanam

\begin{tabular}{lccccc}
\hline \multirow{2}{*}{ Macam media } & \multicolumn{5}{c}{ Diameter Tunas(mm) } \\
\cline { 2 - 6 } & HST & HST & HST & HST & HST \\
\hline Tanah (T) & $0.19 \mathrm{ab}$ & 0.26 & 0.27 & 0.49 & 0.51 \\
T+serbuk gergaji & $0.13 \mathrm{~b}$ & 0.17 & 0.18 & 0.39 & 0.39 \\
T+cocopeat & $0.23 \mathrm{a}$ & 0.27 & 0.32 & 0.42 & 0.48 \\
T+tongkol jagung & $0.17 \mathrm{ab}$ & 0.30 & 0.34 & 0.46 & 0.53 \\
T+seresah daun bambu & $0.19 \mathrm{ab}$ & 0.23 & 0.26 & 0.44 & 0.55 \\
T+arang sekam & $0.22 \mathrm{a}$ & 0.31 & 0.41 & 0.50 & 0.59 \\
\hline BNJ 5\% & 0.098 & - & - & - & - \\
\hline
\end{tabular}

Keterangan: angka-angka yang diikuti dengan huruf yangsama pada kolom yang sama berbeda tidak nyata pada uji lanjut BNJ $5 \%$, HST= Hari setelah tanam.

Macam media berpengaruh nyata terhadap diameter tunas bibit asal stek pada umur 28 HST. Media tanah+cocopeat dan tanah+arang sekam menyebabkan diameter tunas bibit asal stek batang yang lebih besar dibanding dengan media tanah+serbuk gergaji (Tabel 3). Pada umur 28 HST diameter tunas bibit asal stek batang pada media tanah+cocopeat $(0.23 \mathrm{~cm})$, media tanah+arang sekam $(0.22 \mathrm{~cm})$ dan berbeda tidak nyata terhadap media tanah $(0.19 \mathrm{~cm})$, media tanah+seresah daun bambu $(0.19 \mathrm{~cm})$ dan media tanah+tongkol jagung $(0.17 \mathrm{~cm})$. Diameter tunas bibit stek batang terkecil terdapat pada media tanah+serbuk gergaji yakni $0.13 \mathrm{~cm}$. Sedangkan saat umur bibit 42, 56, 70, dan 84 HST media berpengaruh tidak nyata terhadap diameter tunas. Diameter tunas pada umur 84 HST berkisar antara 0.39-0.59 $\mathrm{cm}$.

Macam media pembibitan tanaman asal stek batang kelor berpengaruh nyata $(\mathrm{P}=05$ persen) terhadap jumlah akar dan panjang akar bibit kelor asal stek batang. Pengaruh tersebut adalah bahwa macam media berpengaruh nyata terhadap jumlah akar saat bibit berumur 56 dan 84 HST, namun berpengaruh tidak nyatapada bibit saat berumur 28 HST. Media pembibitan tanaman berpengaruh nyata terhadap panjang akar saat bibit berumur 56 HST, namun berpengaruh tidak nyata pada saat bibit berumur 28 dan 84 HST. Jumlah akar dan panjang akar bibit stek disajikan pada Tabel 4. 
Tabel 4. Jumlah akar dan panjang akar pada berbagai macam media tanam.

\begin{tabular}{lcccccc}
\hline \multirow{3}{*}{ Macam media } & \multicolumn{3}{c}{ jumlah akar } & \multicolumn{3}{c}{ panjang kar $(\mathrm{cm})$} \\
\cline { 2 - 7 } & 28 & 56 & 84 & 28 & 56 & 84 \\
& HST & HST & HST & HST & HST & HST \\
\hline Tanah (T) & 5.20 & $3.33 \mathrm{bc}$ & $16.33 \mathrm{a}$ & 1.64 & $2.84 \mathrm{~b}$ & 9.41 \\
Tanah+serbuk gergaji & 1.00 & $5.33 \mathrm{~b}$ & $11.00 \mathrm{ab}$ & 0.30 & $4.78 \mathrm{ab}$ & 6.02 \\
T+cocopeat & 5.20 & $14.67 \mathrm{a}$ & $16.67 \mathrm{a}$ & 1.66 & $6.94 \mathrm{ab}$ & 9.71 \\
T+tongkol jagung & 6.20 & $11.33 \mathrm{ab}$ & $17.33 \mathrm{a}$ & 0.90 & $6.26 \mathrm{ab}$ & 11.73 \\
T+seresah daun bambu & 6.33 & $7.40 \mathrm{~b}$ & $16.33 \mathrm{a}$ & 1.71 & $6.82 \mathrm{ab}$ & 13.80 \\
T+arang sekam & 5.40 & $7.00 \mathrm{~b}$ & $7.67 \mathrm{~b}$ & 1.91 & $8.69 \mathrm{a}$ & 12.99 \\
\hline \multicolumn{1}{c}{ BNJ 5\% } & - & 8.60 & 6.60 & - & 5.34 & - \\
\hline
\end{tabular}

Keterangan: angka-angka yang diikuti dengan huruf yang sama pada kolom yang sama berbeda tidak nyata pada uji lanjut BNJ $5 \%$, HST= Hari setelah tanam.

Media tanam bibit asal stek berpengaruh nyata terhadap jumlah akar saat bibit asal stek berumur 56 dan 84 HST. Jumlah akar terbanyak pada saat bibit asal stek berumur 56 HST terdapat pada media tanah+cocopeat (14.67), dan berbeda tidak nyata dengan media tanah+tongkol jagung (11.33), namun berbeda nyata dengan media tanah+tanah seresah daun bambu (7.4), tanah+arang sekam (7) dan tanah+serbuk gergaji (5.33). Jumlah akar stek batang kelor terendah terdapat pada media tanah (3.33).Pada saat bibit asal stek berumur 84 HST jumlah akar bibit stek tertinggi terdapat pada media tanah+tongkol dan jumlah akar terendah terdapat pada media tanah+arang sekam (Tabel 4.).

Media berpengaruh tidak nyata terhadap panjang akar bibit asal stek batang kelor pada umur 28 HST dan 84. Sedangkan pada saat bibit asal stek berumur 56 HST macam media berpengaruh nyata terhadap panjang akar bibit asal stek batang kelor. Akar bibit stek batang terpanjang pada umur 56 HST terdapat pada media tanah+arang sekam $(8.69 \mathrm{~cm})$ dan berbedatidak nyata terhadap media tanah+serbuk gergaji $(4.78 \mathrm{~cm})$, media tanah+cocopeat $(6.94 \mathrm{~cm})$, media tanah+tongkol $(6.26 \mathrm{~cm})$, dan media tanah+seresah daun bambu $(6.82 \mathrm{~cm})$. Akar bibit asal stek terpendek terdapat pada media tanah $(2.84 \mathrm{~cm})$. Pertumbuhan bibit selanjutnya dan tanaman muda hingga tanaman mencapai dewasa ditentukan oleh sistim perakarannya. Arsitektur atau sistim perakaran mendukung percepatan pertumbuhan tanaman dari sejak tahap awal pertumbuhan melalui kemampuannya mengekstrak ketersediaan air pada lapisan tanah dangkal (atas) yang mudah hilang karena evaporasi (Johansen et al. 1997) dan juga kemampuan mengekstrak air dari lapisan tanah dalam akan mendukung kemampuan tanaman beradaptasi (Kashiwagi et al. 2006).

Macam media berpengaruh tidak nyata pada bobot segar tunas (Tabel 7.). Bobot segar tunas bibit kelor asal stek batang hingga umur 3 bulan berkisar antara 45.02-149. Sedangkan macam media tanam terhadap bobot kering tunas berpengaruh nyata pada saat bibit asal stek batang berumur 56 HST, namun berpengaruh tidak nyata pada saat tanaman berumur 28 HST dan 84 HST. Bobot segar dan bobot kering tunas disajikan pada Tabel 5.

Macam media berpengaruh nyata terhadap bobot kering tunas pada umur pengamatan 56 HST dengan bobot kering tunas paling berat terdapat pada media tanah+cocopeat yakni 12.62 g. dan berbeda tidak nyata terhadap media tanah+seresah daun bambu (9.02 g), tanah+arang sekam (8.07 g), tanah+serbuk gergaji (6.72 g). Sedangkan bobot kering tunas pada media tanah paling rendah yakni 2.02 g. Zulyana, (2011) menyatakan bahwa, bobot kering tanaman akan meningkat jika fotosintesis meningkat, sehingga unsur hara akan 
terserap seiring dengan berjalannya proses fotosintesis. Jumlah unsur hara yang terserap akan berpengaruh terhadap tinggi rendahnya berat kering tanaman.

Tabel 5. Bobot segar dan bobot kering tunas pada berbagai macam media tanam.

\begin{tabular}{lcccccc}
\hline \multirow{1}{*}{ Macam media } & \multicolumn{3}{c}{ bobot segar tunas $(\mathrm{g})$} & \multicolumn{3}{c}{ bobot kering tunas $(\mathrm{g})$} \\
\cline { 2 - 7 } & 28 & 56 & 84 & 28 & 56 & 84 \\
& HST & HST & HST & HST & HST & HST \\
\hline Tanah (T) & 1.34 & 20.67 & 110.33 & 0.26 & $2.02 \mathrm{~b}$ & 21.01 \\
T+serbuk gergaji & 0.21 & 35.67 & 45.02 & 0.05 & $6.72 \mathrm{ab}$ & 6.93 \\
T+cocopeat & 1.47 & 77.50 & 115.67 & 0.27 & $12.62 \mathrm{a}$ & 21.74 \\
T+tongkol jagung & 0.76 & 61.25 & 98.33 & 0.15 & $9.33 \mathrm{ab}$ & 18.97 \\
T+seresah daun bambu & 2.40 & 55.10 & 98.33 & 0.44 & $9.02 \mathrm{ab}$ & 18.62 \\
T+arang sekam & 0.22 & 51.14 & 149 & 0.15 & $8.07 \mathrm{ab}$ & 29.07 \\
\hline BNJ 5\% & - & - & - & - & 8.75 & - \\
\hline
\end{tabular}

Keterangan : angka-angka yang diikuti dengan huruf yang sama pada kolom yang sama berbeda tidak nyata pada uji lanjut BNJ $5 \%$, HST= Hari setelah tanam.

Dalam penelitian ini diperoleh bahwa macam media berpengaruh tidak nyatan terhadap bobot segar dan bobot kering akar pada umur bibit tanaman 28 HST dan 84 HST akan tetapi berpengaruh nyata terhadap bobot segar dan bobot kering akar pada umur 56 HST. Bobot segar dan bobot kering akar disajikan pada Tabel 6.

Tabel 6. Bobot segar dan bobot kering akar pada berbagai macam media tanam.

\begin{tabular}{lcccccc}
\hline \multirow{2}{*}{ Macam media } & \multicolumn{3}{c}{ berat segar akar $(\mathrm{g})$} & \multicolumn{3}{c}{ berat kering akar $(\mathrm{g})$} \\
\cline { 2 - 7 } & 28 & 56 & 84 & 28 & 56 & 84 \\
& HST & HST & HST & HST & HST & HST \\
\hline Tanah (T) & 0.02 & $0.62 \mathrm{~b}$ & 12.33 & 0.004 & $0.19 \mathrm{c}$ & 1.98 \\
T+serbuk gergaji & 0.01 & $1.98 \mathrm{ab}$ & 4.09 & 0.001 & $0.41 \mathrm{bc}$ & 0.45 \\
T+cocopeat & 0.07 & $5.10 \mathrm{a}$ & 11.67 & 0.011 & $1.28 \mathrm{a}$ & 2.16 \\
T+tongkol jagung & 0.03 & $2.42 \mathrm{ab}$ & 13.33 & 0.002 & $0.52 \mathrm{abc}$ & 2.91 \\
T+seresah daun bambu & 0.08 & $2.78 \mathrm{ab}$ & 16.67 & 0.059 & $0.76 \mathrm{abc}$ & 3.15 \\
T+arang sekam & 0.03 & $4.45 \mathrm{ab}$ & 61.33 & 0.016 & $1.21 \mathrm{ab}$ & 10.11 \\
\hline \multicolumn{1}{c}{ BNJ 5\% } & - & 4.28 & - & - & 0.86 & - \\
\hline
\end{tabular}

Keterangan: angka-angka yang diikuti dengan huruf yang sama pada kolom yang sama berbeda tidak nyata pada uji lanjut BNJ $5 \%$, HST= Hari setelah tanam.

Media pembibitan stek batang kelor berpengaruh nyata terhadap bobot segar akar stek batang pada umur pengamatan 56 HST. Bobot segar akar bibit asal stek batang yang paling berat terdapat pada media tanah+cocopeat yakni $5.10 \mathrm{~g}$ dan berbeda tidak nyata terhadap bobot segar akar pada media tanah+arang sekam (4.45 g), tanah+seresah daun bambu (2.78 g), tanah+tongkol (2.42 g), tanah +serbuk gergaji (1.98 g) dan bobot segar akar terendah terdapat pada media tanah yakni $0.62 \mathrm{~g}$.

Macam media pembibitan stek batang kelor berpengaruh nyata terhadap bobot kering akar stek batang kelor pada umur 56 HST. Bobot kering akar stek batang kelor paling berat terdapat pada media tanah+cocpeat yakni $1.28 \mathrm{~g}$, dan berbeda tidak nyata dengan media 
tanah+arang sekam (1.21 g), media tanah+seresah daun bambu (0.76 g), media tanah+tongkol jagung $(0.52 \mathrm{~g})$, namun pada media tanah, bobot kering akar paling rendah yakni $0.19 \mathrm{~g}$. Bobot kering akar merupakan akumulasi senyawa organik dan terkait dengan pertumbuhan panjang akar, semakin panjang akar maka akan menghasilkan bobot kering akar yang lebih besar (Sofyan et al., 2014).

Media pembibitan berupa campuran tanah + arang sekam memiliki kadar air paling tinggi dengan media pembibitan lainnya yaitu $32.04 \%$, kemudian disusul dengan media tanah+cocopeat yaitu $27.09 \%$, media campuran tanah+serbuk gergaji (22.67\%), media tanah (20.57\%), tanah+seresah daun bambu (18.31\%), dan kada air paling rendah pada media tanah+tongkol jagung (16.10\%). Sedangkan media dengan berat jenis yang tinggi yaitu media tanah $\left(2.07 \mathrm{~g} . \mathrm{ml}^{-1}\right)$, tanah+hancuran tongkol jagung (2.00 g.ml $\left.{ }^{-1}\right)$, tanah-seresah daun bambu (2.03 g. $\mathrm{ml}^{-1}$ ). Media dengan berat jenis yang rendah yakni media tanah+serbuk gergaji $\left(1.91 \mathrm{~g} \cdot \mathrm{ml}^{-1}\right)$, lebih tinggi jika dibandingkan dengan media tanah+arang sekam $\left(1.83 \mathrm{~g} \cdot \mathrm{ml}^{-1}\right)$ dan tanah+cocopeat $\left(1.66 \mathrm{~g} \cdot \mathrm{ml}^{-1}\right)$.

Berat jenis berkaitan erat dengan porositas media.Jika berat jenis media tinggi maka porositasnya rendah, begitu juga sebaliknya jika berat jenis rendah maka porositasnya tinggi. Sehingga dapat dikatakan bahwa media tanah, tanah-hancuran tongkol jagung, tanah+seresah daun bambu memiliki porositas yang rendah, sedangkan media tanah+serbuk gergaji, media tanah+arang sekam dan tanah+cocopeat memiliki porositas yang lebih tinggi.

Komponen kimia media berperan dalam menentukan sifat dan ciri media pada umumnya dan kesuburan media pada khususnya. Komponen kimia media pembibitan stek batang kelor disajikan pada Tabel 7.

Table 7. Komponen kimia pada masing-masing media pembibitan stek batang kelor

\begin{tabular}{lccccccc}
\hline \multicolumn{1}{c}{ Macam media } & pH-H2O & $\begin{array}{c}\text { N- } \\
\text { total } \\
(\%)\end{array}$ & $\begin{array}{c}\text { C-organik } \\
(\%)\end{array}$ & $\begin{array}{c}\text { KTK } \\
(\mathrm{cmol} / \mathrm{kg})\end{array}$ & $\begin{array}{c}\text { P-tersedia } \\
(\mathrm{ppm})\end{array}$ & $\begin{array}{c}\text { K-Tersedia } \\
(\mathrm{ppm})\end{array}$ & $\mathrm{C} / \mathrm{N}$ \\
\hline Tanah (T) & $5.60 \mathrm{AM}$ & $0.16 \mathrm{R}$ & $0.29 \mathrm{SR}$ & $12.56 \mathrm{R}$ & $5.50 \mathrm{~S}$ & $48.32 \mathrm{ST}$ & $1.81 \mathrm{SR}$ \\
T+serbuk gergaji & $6.23 \mathrm{AM}$ & $0.17 \mathrm{R}$ & $1.59 \mathrm{R}$ & $12.95 \mathrm{R}$ & $13.86 \mathrm{ST}$ & $52.64 \mathrm{ST}$ & $9.35 \mathrm{R}$ \\
T+cocopeat & $5.84 \mathrm{AM}$ & $0.16 \mathrm{R}$ & $0.73 \mathrm{SR}$ & $13.96 \mathrm{R}$ & $9.03 \mathrm{~T}$ & $52.12 \mathrm{ST}$ & $4.56 \mathrm{SR}$ \\
T+tongkol jagung & $5.88 \mathrm{AM}$ & $0.20 \mathrm{R}$ & $0.98 \mathrm{R}$ & $14.36 \mathrm{R}$ & $8.54 \mathrm{~T}$ & $56.86 \mathrm{ST}$ & $4.90 \mathrm{SR}$ \\
T+seresah & & & & & & & \\
daun bambu & $5.90 \mathrm{AM}$ & $0.14 \mathrm{R}$ & $1.45 \mathrm{R}$ & $17.34 \mathrm{~S}$ & $8.75 \mathrm{~T}$ & $51.48 \mathrm{ST}$ & $10.36 \mathrm{R}$ \\
T+arang sekam & 6.01 AM & $0.17 \mathrm{R}$ & $1.75 \mathrm{R}$ & $22.36 \mathrm{~S}$ & $13.87 \mathrm{ST}$ & $37.25 \mathrm{ST}$ & $10.29 \mathrm{R}$ \\
\hline
\end{tabular}

Keterangan :Kriteria sifat kimia berdasarkan kriteria Balai Penelitian Tanah (2005). AM = agak masam. $\mathrm{SR}=$ sangat rendah. $\mathrm{R}=$ rendah $. \mathrm{S}=$ Sedang. $\mathrm{T}=$ Tinggi. $\mathrm{ST}=$ Sangat tinggi

Kemasaman $(\mathrm{pH})$ pada semua media pembibitan tergolong agak masam, yakni berkisar antara 5.60-6.23. Amaglo (2006) menyatakan bahwa salah satu syarat tumbuh tanaman kelor yaitu $\mathrm{pH}$ tanah berkisar antara 5.0-9.0, sehingga $\mathrm{pH}$ media pembibitan yang digunakan dalam penelitian ini cocok untuk pertumbuhan bibit asal stek batang kelor.Hara yang sangat dipengaruhi oleh $\mathrm{pH}$ antara lain kalsium dan magnesium dapat ditukar, aluminium dan unsur mikro, ketersediaan fosfor. Bila $\mathrm{pH}$ tanah mineral rendah, sejumlah $\mathrm{Al}$, Fe dan Mn menjadi sangat larut, sehingga merupakan racun bagi tanaman.

Berdasarkan hasil analisis media pembibitan terkait C-organik, maka yang tergolong sangat rendah yaitu, media tanah, tanah+cocopeat. Sedangkan kandungan C-organik pada 
media tanah+serbuk gergaji, tanah+seresah daun bambu, tanah+arang sekamdan tanah+hancuran tongkol jagung tergolong sedang.

Media pembibitan dengan KTK (Kapasitas Tukar Kation) tergolong rendah yaitu tanah, tanah+serbuk gergaji, tanah-cocopeat, dan tanah+hancuran tongkol jagung. Sedangkan media tanah+seresah daun bamboo dan media tanah+arang sekam memiliki KTK yang tergolong sedang.KTK merupakan sifat kimia yang sangat erat hubungannya dengan kesuburan tanah. Tanah-tanah dengan kandungan bahan organik atau kadar liat tinggi mempunyai KTK lebih tinggi dari pada tanah dengan kandungan bahan organik rendah atau tanah-tanah berpasir (Hardjowogeno 2007)

Semua macam media pembibitan yang digunakan dalam penelitian ini memiliki kandungan N-total yang tergolong rendah. Sutanto (2005) menyatakan bahwa rendahnya kandungan bahan organik sejalan dengan rendahnya kandungan $\mathrm{N}$-total karena sumber $\mathrm{N}$ dalam tanah adalah bahan organik yang telah mengalami dekomposisi.

Berdasarkan hasil analisis, media tanah memiliki kandungan unsur P-tersedia yang tergolong sedang. Ketersediaan unsur $\mathrm{P}$ yang tergolong tinggi yaitu pada media tanah+cocopeat, tanah+tongkol jagung, dan tanah+seresah daun bambu. Sedangkan kadar Ptersedia pada media tanah+seruk gergaji dan media tanah+arang sekam tergolong sangat tinggi. Unsur K-tersedia yang terdapat pada semua macam media pembibitan yang digunakan dalam penelitian ini tergolong sangat tinggi.

Penggunaan bahan baku media pembibitan dalam penelitian ini relatif masih segar, terutama bahan serbuk gergaji, cocopeat, dan tongkol jagung sehingga memiliki nilai $\mathrm{C} / \mathrm{N}$ yang tinggi. Namun, bahan baku tersebut mengalami dekomposisi selama periode waktu 3 bulan percobaan. Hal ini dapat dilihat dari nilai $\mathrm{C} / \mathrm{N}$ yang tergolong sangat rendah pada media tanah, tanah+cocopeatdan tanah+hancuran tongkol jagung.Sedangkan media yang tergolong $\mathrm{C} / \mathrm{N}$ ratio rendah yaitu tanah+serbuk gergaji, tanah+seresah daun bambu, dan tanah+arang sekam.

Djuarnani et al., (2009) menyatakan bahwa apabila C/N rasio sangat tinggi, nitrogen akan digunakan dengan sangat cepat oleh bakteri metan dan sebagai akibatnya produksi metan akan menjadi rendah. Sebaliknya apabila $\mathrm{C} / \mathrm{N}$ rasio sangat rendah, nitrogen akan bebas dan akan terakumulasi dalam bentuk amoniak $\left(\mathrm{NH}_{4}{ }^{+}\right)$yang mudah diabsorpsi akar tanaman.

Hasil penelitian kami menunjukkan bahwa perbanyakan vegetatif kelor sangat penting. Seperti yang dikatakan Santoso dan Parwata (2014) bahwa seperti halnya pada tanaman jarak pagar yang bersifat penyerbukan bebas (heterozigot), demikian pula halnya dengan tanaman kelor, maka suksesnya pembentukan sistim perakaran pada stek batang merupakan hal penting. Sehubungan dengan itu, maka pemilihan macam media pembibitan juga perlu mendapat perhatian.

\section{KESIMPULAN}

1. Pada bibit kelor berumur 3 bulan, macam media berpengaruh tidak nyata terhadap sebagian besar variabel pertumbuhan bibit stek kecuali jumlah daun dan jumlah akar, namun media nampak berpengaruh nyata terhadap pertumbuhan bibit stek pada saat bibit berumur 2 bulan.

2. Media yang baik untuk digunakan dalam pembibitan kelor dengan stek batang yaitu media tanah+arang sekam, tanah+cocopeat, dan tanah+seresah daun bambu. 


\section{DAFTAR PUSTAKA}

Aminah, S., Ramdhan, T., Yanis, M. 2015.Kandungan Nutrisi dan Sifat Fungisional Tanaman Kelor (Moringa Oleifera). Buletin Pertanian Perkotaan, 5 (2): 35-44.

Ashari, S., 2006. Hortikultura Aspek Budidaya. UI Press, Jakarta.

Amaglon N.K., Timpo G. M., Elis W. O. and Bennett R.N. 2006. Effect of Spacing and Harvest Frecuency onThe Growth and Leaf Yiledof Moringa (Moringa Oleifera Lam.), a Leafy Vegetable Crop. Moringa and Other Highly Nutritious Plant Resources: Strategies, Standards and Markets For a Better Impact on Nutrition In Africa. International Workshop on Moringa: Accra, 16-18 November 2006.

Anwarudin M. J., Indriyani,N. L. P., Hadiati,S., Mansyah, E. 1996. Pengaruh Konsentrasi Asam Giberelat dan Lama Perendaman Terhadap Perkecambahan dan Pertumbuhan Biji Manggis. Jurnal Hortikultura 6 (1):1-5

Balai Penelitian Tanah. 2005. Petunjuk Teknis Analisis Kimia Tanah, Tanaman, Air, dan Pupuk. Balai Penelitian Tanah. Bogor.

Badan Meteorologi, Klimatologi dan Geofisika. 2017. Data Iklim Bulan Januari, Februari, Maret, April Tahun 2017 di Lombok Barat dan Mataram. Stasiun Klimatologi Kelas I Lombok Barat.NTB.

Djuarnani, N., Kristian.,Setiawan,B. S. 2004. Cara Cepat Membuat Kompos Agro Media Pustaka. Hal 23-25.

Hardjowigeno, S., 2007. Ilmu Tanah. Akademika Pressindo: Jakarta.

Hartman, H.T., Kester,D.E., Davies,F.T., Geneve,R.L. 2002. Plant Propagation Principles and Practiese, $6^{\text {th }}$ Ed. New Delhi: Prentice Hall of India Private Limited.

Indriyani, S., E.L. Arumingtyas \& R. Azrianingsih. 1999. Variabilitas Isonenzim Pada Kacang Hijau (Phaseolus actor L.). Natural, 1(1):3-8

Krisnadi, A.D. 2015. Kelor Super Nutrisi. Kelorina.com.http://kelorina.com/blog /ebookkelor-super-nutrisi/ [17 November 2016].

Laboratorium Tanah, Tanaman, Pupuk, Air. 2017. Laporan Hasil Sampel Pembibitan. Balai Pengkajian Teknologi Pertanian NTB. NTB.

Mendieta, A. B., Spörndly, E., Reyes, S. N., Salmerón, M. F., Halling, M. 2013. Biomass production and chemical composition of Moringa oleifera under different planting densities and levels of nitrogen fertilization. Agroforest Syst, 87:81-92.

Prajapati, R.D., Murdia, P.C., Yadav, C.M., Chaudhary, J.L., 2003. Nutritive Value of Drumstick (Moringa oleifera) Leaves in Sheep and Goats. Indian Journal of Small Ruminants (2):136-137.

Santoso, B.B., Hariyadi., Purwoko B. S. 2009. Pertumbuhan Bibit Jarak Pagar Asal Biji dan Stek pada Berbagai Macam Media Pembibitan.Crop Agro. 2 (2): 1-11

Santoso, BB., parwata, IGM.A. 2014. Seedling Growth from Stem Cutting with Different Physiological Ages of Jatrophacurcas L. of West Nusa Tenggara Genotypes. Int. J. App. Sci. and Tech. 4 (6):5-10

Santoso, B.B., Parwata, IGMA., Soemeinaboedhy, IN. 2017. Pembibitan tanaman Kelor (Moringa oleifera Lam). Arga Puji Press. 79p.

Santoso, B.B., Parwata, IGMA. 2017. Viabilitas Biji dan Pertumbuhan Bibit Kelor (Moringa oleifera Lam.). J. Sains Teknologi \& Lingkungan, 3(2):1-8.

DOI: https://doi.org/10.29303/jstl.v3i2.18 
Simbolan J.M., Simbolan, M., Katharina, N., 2007. Cegah Malnutrisi Dengan Kelor. Yogyakarta: kanisius.

Sofyan, A., Nurjaya, Kasno, A. 2004. Setatus Hara Tanah Sawah Untuk Rekomendasi Pemupukan. Dalam: Tanah Sawah dan Teknologi Pengelolaannya. Hlm. 83-114. Pusat Penelitian dan Pengembangan Tanah Dan Agroklimat. Bogor.

Susanto, R. 2005. Dasar-dasar Ilmu Tanah: Kanisius. Yogyakarta.

Thompson, L.M. and FdR. Troeh 1978. Soil and soil fertility. $2^{\text {nd }}$ ed. McGraw-Hill Book Co., New York.451 p.

Zulyana, U. 2011. Respon Ketimun (Cucumis sativus) Terhadap Pemberian Kombinasi Dosis Dan Macam Bentuk Pupuk Kotoran Sapi Di Getasan. [Skripsi]. Program Studi Agronomi, Fakultas Pertanian Universitas Sebelas Maret. Surakarta. 